\title{
Physiological and biochemical indicators of mussel seed quality in relation to temperatures
}

\author{
Réjean Tremblay ${ }^{1, a}$, Thomas Landry ${ }^{2}$, Neil Leblanc ${ }^{5}$, Fabrice Pernet $^{3}$, Carla Barkhouse ${ }^{2}$ \\ and Jean-Marie Sévigny ${ }^{4}$ \\ 1 Institut des sciences de la mer- UQAR, 310 allée des Ursulines, Rimouski, Québec, G5L 3A1, Canada \\ 2 Department of Fisheries and Oceans, Aquaculture and Coastal Ecosystem Section, Gulf Fisheries Centre, Moncton, NB, E1C 9B6, Canada \\ 3 IFREMER, Laboratoire Environnement Ressources en Languedoc-Roussillon, Pôle "Mer et Lagunes", Bd Jean Monnet, BP 171, \\ 34203 Sète Cedex, France \\ ${ }^{4}$ Pêches et Océans Canada, Direction des sciences halieutiques et aquaculture, Institut Maurice-Lamontagne, 850 Route de la Mer, Mont-Joli, \\ Québec, G5H 3Z4, Canada \\ 5 National Veterinary Institute (SVA), Ullsväg 2B, 75189 Uppsala, Sweden
}

Received 12 February 2011; Accepted 13 May 2011

\begin{abstract}
The bivalve's aquaculture industry is an important component of the economy in Eastern Canada. Seed collection is an initial and critical activity in most bivalve aquaculture industries including mussel farming in Prince Edward Island, production is entirely dependent on natural spat collection. Although seed supply is not a concern from a quantitative standpoint, there are growing concerns about the quality of natural seed. The general objective of this study was to identify and assess mussel seed quality criteria on the basis of physiological and biochemical status under laboratory and field conditions. The performance, as estimated by metabolic measurements, lipid class composition, multi-locus heterozygosity (MLH) and survival to stressful environment of seed from 6 different stocks sources was first compared under laboratory conditions at $12{ }^{\circ} \mathrm{C}$ and $25^{\circ} \mathrm{C}$. Results showed that MLH varied among the six sources of mussels in a way which is consistent with the physiological and biochemical indicators of seed quality. Mussels from Shippagan (New Brunswick) and Tracadie (Prince Edward Island) were found to have the highest quality scores and the best adaptive capacity to extreme water temperature under laboratory conditions. The results of the stock-site reciprocal field studies are in general agreement with those of the laboratory experiments with higher survival of mussels from Shippagan, Tracadie and St. Peters Bays in the various study sites. Our results suggest that the measure of MLH and survival curves at stressful temperature could be a good criteria combination to identify the improved survival potential of mussels stocks.
\end{abstract}

Key words: Wild seed / aquaculture / physiological fitness / growth / survival / multi-locus heterozygosity / Mytilus spp.

\section{Introduction}

Mytilus spp. have a high dispersal potential, mostly due to their planktonic larval stage, which last several weeks, and their drifting capacity through byssus production during their initial post-larval stage (Lane et al. 1985; Siegel et al. 2003). Coupled with large population sizes and high fecundity, mussel populations can maintain high levels of gene flow and a relatively weak population structure (Palumbi 1992). However, interactions between isolated pulses of larval settlement and turbulent coastal circulations have been related to stochastic processes of larval settlement (Nicastro et al. 2008; Siegel et al. 2008). This phenomenon along with selective pre and post-settlement mortality could explain the genetic differentiation sometimes observed between mussel stocks from different

\footnotetext{
a Corresponding author: rejean_tremblay@uqar.qc.ca
}

bays (Tremblay et al. 1998a; Ridgway 2001; Star et al. 2003; Toro et al. 2004; Moreau et al. 2005; Johnson and Geller 2006; Beaumont et al. 2008).

Previous studies conducted on blue mussel stocks used for aquaculture showed that genetic differentiation over a small geographical scale (less than $50 \mathrm{~km}$ ) was related to differential sensitivity associated with stressful events (Myrand et al. 2002; LeBlanc et al. 2005). The high susceptibility of mussels to stress was related to higher maintenance requirements and low multiple-locus heterozygosity (Myrand et al. 2002; LeBlanc et al. 2008). These results were in good agreement with several studies that indicated that more heterozygous individuals had a higher protein synthesis efficiency and a higher scope for growth compared to more homozygous individuals (Hawkins et al. 1989). However, no tools are available to identify the potential resistance of seed mussels to stressful environments, 


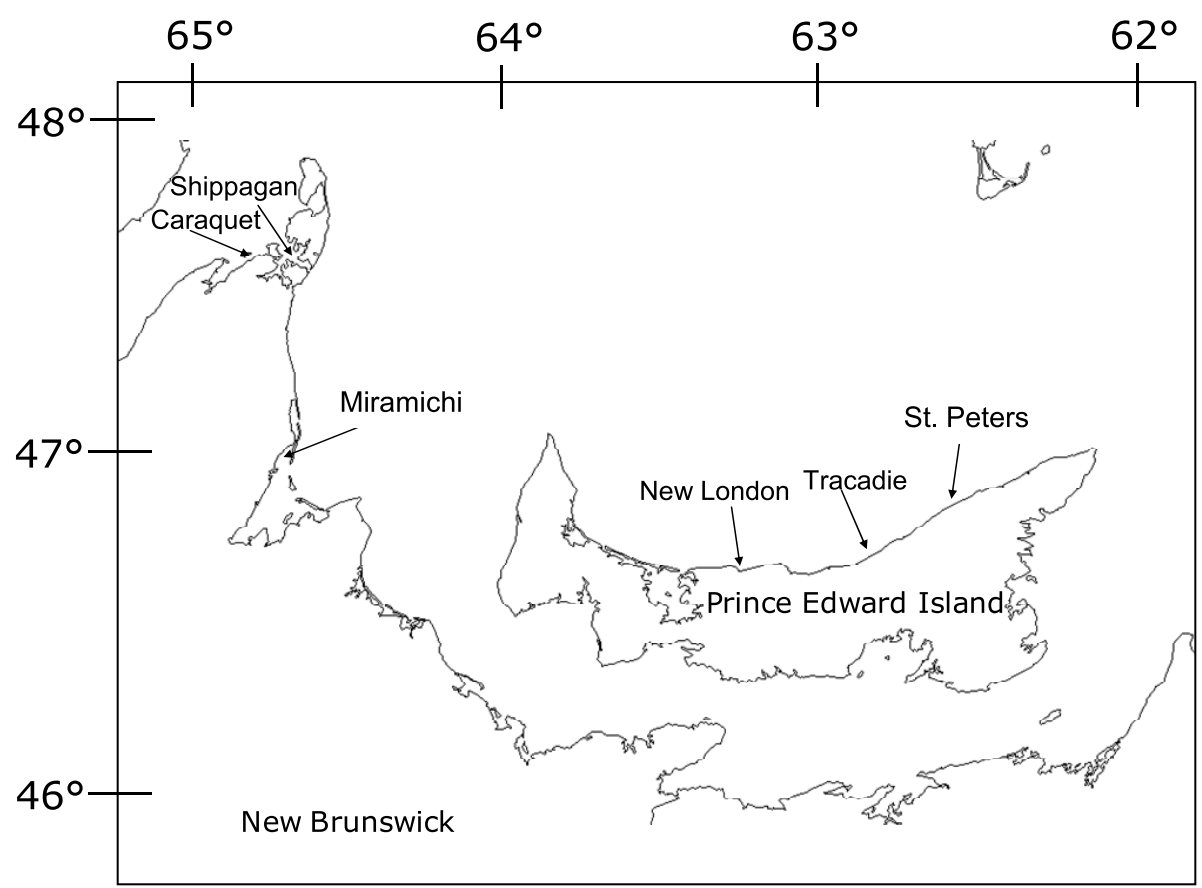

Fig. 1. Map of the southern Gulf of St Lawrence. Study sites in New Brunswick are the baie de Néguac (Miramichi), baie de Caraquet, and baie de Shippigan; New London Bay, Tracadie Bay, and St. Peters Bay are located in Prince Edward Island.

particularly to high temperatures experienced by aquaculture mussels in the southern Gulf of St Lawrence, which can reach $25{ }^{\circ} \mathrm{C}$ in summer.

In this study, we tested the hypothesis that fitness-related mussel traits in aquaculture sites, particularly survival rate, could be linked to genetic characteristics and identified by physiologically based indicators. The main objective was to determine physiological and biochemical indicators of mussel seed quality from larvae collected at different locations in the Gulf of St. Lawrence (Canada). More specifically, our objectives were 1) to determine lipid composition, metabolic level, and multi-locus heterozygosity in relation to the physiological performance of mussels from different sites and 2) to develop practical evaluation methods to assess physiological fitness at the individual and population level.

\section{Materials and methods}

\subsection{Experimental sites}

On 20 October 2004, mussel seed was collected from six suspended culture sites in the southern Gulf of St. Lawrence (Canada, Fig. 1). Three culture sites were located in New Brunswick: Caraquet $\left(47.8197^{\circ} \mathrm{N}, 64.8756^{\circ} \mathrm{W}\right)$, Shippagan $\left(47.7771^{\circ} \mathrm{N}, 64.68691^{\circ} \mathrm{W}\right.$ ), and Miramichi (near Neguac, $47.2437^{\circ} \mathrm{N}, 65.0384^{\circ} \mathrm{W}$ ), and three other sites in Prince Edward Island: New London $\left(46.4805^{\circ} \mathrm{N}, 63.4669^{\circ} \mathrm{W}\right)$, Tracadie $\left(46.4006^{\circ} \mathrm{N}, 62.9946^{\circ} \mathrm{W}\right)$, and St. Peters Bay $\left(46.4281^{\circ} \mathrm{N}, 62.6422^{\circ} \mathrm{N}\right)$. At each site, several thousand seed mussels of similar length $(21.5 \pm 4.4 \mathrm{~mm})$ were randomly sampled from suspended artificial collectors (Mallet and Myrand 1995), transported on ice to the Canadian Department of Fisheries and Oceans Gulf Fisheries Centre in Moncton, NB, and held in aquaria with aerated and filtered seawater at $10^{\circ} \mathrm{C}$ (ambient seawater temperature) and a salinity of 25 . Subsamples of 40 mussels per stock were collected for genetic analyses. In addition, 600 live specimens per stock were randomly selected and transported (within $24 \mathrm{~h}$ ) to the Centre Aquacole Marin de Grande-Rivière (CAMGR, Québec, Canada) for thermal acclimation and a stress experiment. Finally, 288 mussels per stock were used for a reciprocal transplant (stocks-sites) field experiment.

\subsection{Genetic characterization of mussels}

The Gulf of St Lawrence is a region where two morphologically similar blue mussel species, Mytilus edulis and M. trossulus, coexist. Therefore, we used molecular markers for species discrimination on the sub-samples used for genetic characteristics. DNA extractions were performed on foot sections using the QIAGEN ${ }^{\circledR}$ DNeasy ${ }^{\text {tm }}$ Tissue Kit. The ITS nuclear markers (Heath et al. 1995), a co-dominant DNA marker with distinct patterns for M. edulis, M. trossulus as well as for the hybrids was used for species determination.

A small piece of digestive gland was collected from each of 40 mussels per stock, and frozen separately at $-80{ }^{\circ} \mathrm{C}$ for allozyme analyses. The methods (extraction and electrophoresis) used for studying variations of allozyme loci are the same as those described in Tremblay et al. (1998a). Allozymes studied were mannose phosphate isomerase (MPI, EC 5.3.1.8), phosphoglucomutase (PGM, EC 2.7.5.1), octopine dehydrogenase $(O D H, \mathrm{EC} 1.5 .1 .11)$, glucose phosphate isomerase (GPI, EC 5.3.1.9), and leucine aminopeptidase (LAP, EC 3.4.11). A standard consisting of a mixture of individuals having all alleles present at each locus was used to ensure proper allele identification. 


\subsection{Thermal acclimation experiment}

Upon arrival at CAMGR, mussels were fed continuously with a 1:1 mixture of Isochrysis galbana and Chaetoceros gracilis at a concentration of $10^{4}$ cells $\mathrm{ml}^{-1}$. Mussels were maintained at ambient temperature $\left(5-7^{\circ} \mathrm{C}\right)$ in filtered seawater $(1 \mu \mathrm{m})$ for one week. After this period, mussels from all six stocks were gradually exposed to temperatures of either $12{ }^{\circ} \mathrm{C}$ or $25{ }^{\circ} \mathrm{C}$ (Fig. 2); $25{ }^{\circ} \mathrm{C}$ is the maximum temperature encountered by mussels in these areas. For each temperature treatment, mussels from each stock were separated into three tanks (6 mussels/stock/tank). Temperature was raised at a rate of $1{ }^{\circ} \mathrm{C}$ per day to reach $12{ }^{\circ} \mathrm{C}$ and at a rate of $2-3{ }^{\circ} \mathrm{C}$ per day to reach $25^{\circ} \mathrm{C}$.

\subsection{Sampling and lipid analyses}

On day 1 and day 8 (Fig. 2) of the thermal acclimation experiment, six mussels from each of the six stocks were randomly sampled for a total of 72 mussels. On days 15 and 36 , six mussels per stock at $12{ }^{\circ} \mathrm{C}$ and $25{ }^{\circ} \mathrm{C}$ were sampled for a total of 144 mussels. For each sample, the entire individual was removed from its shell, weighed, randomly paired with another individual from the same treatment, and frozen at $-80{ }^{\circ} \mathrm{C}$. The samples therefore consist of two mussels per sample, and three samples per stock, date, and per temperature combination. Lipids were extracted (Folch et al. 1957) and classes determined by thin layer chromatography after separation into aliphatic hydrocarbons, wax esters, ketones, triacylglycerols, free fatty acids, free fatty alcohol, sterols, diacylglycerols, acetone mobile polar lipids and phospholipids, using TLC Chromarods-SIII for Iatroscan MK-VI (Iatron Laboratories Inc., Tokyo, Japan) as already described (Parrish 1999). Chromatograms were analyzed using Peak Simple version 3.2 (SRI Inc, Torrance, CA, USA).

\subsection{Metabolic rate measurements}

As described in Myrand et al. (2002), maximum metabolism (obtained after ingestion near the maximal rate) and standard metabolism (obtained after starvation) were determined by measuring the oxygen consumption. On day 36, the production of pseudofaeces confirmed that ingestion rate was near its maximum (Thompson and Bayne 1972), so maximum metabolism was determined by measuring oxygen uptake by 24 mussels from each stock. Individual mussels were held in a respirometry chamber $(500 \mathrm{ml})$ filled with oxygensaturated seawater that had been filtered $(0.45 \mu \mathrm{m})$ and treated with UV light. Each mussel was acclimated to the respirometry chamber for $1 \mathrm{~h}$ at the temperature treatment. Partial oxygen pressure was greater than 100 torr and water was kept wellmixed using a magnetic stirrer. Oxygen consumption was determined by sealing the metabolic chambers and measuring the decrease in dissolved oxygen with a YSI (5331) polarographic electrode coupled to a YSI micro-oxymeter (Yellow Springs, $\mathrm{OH}, \mathrm{USA}$ ). The output signal was monitored continuously on a chart recorder until there was a $20 \%$ decrease in oxygen saturation. These specimens were then maintained at the same temperature regime $\left(12{ }^{\circ} \mathrm{C}\right.$ and $\left.25^{\circ} \mathrm{C}\right)$ and starved for 10 days in

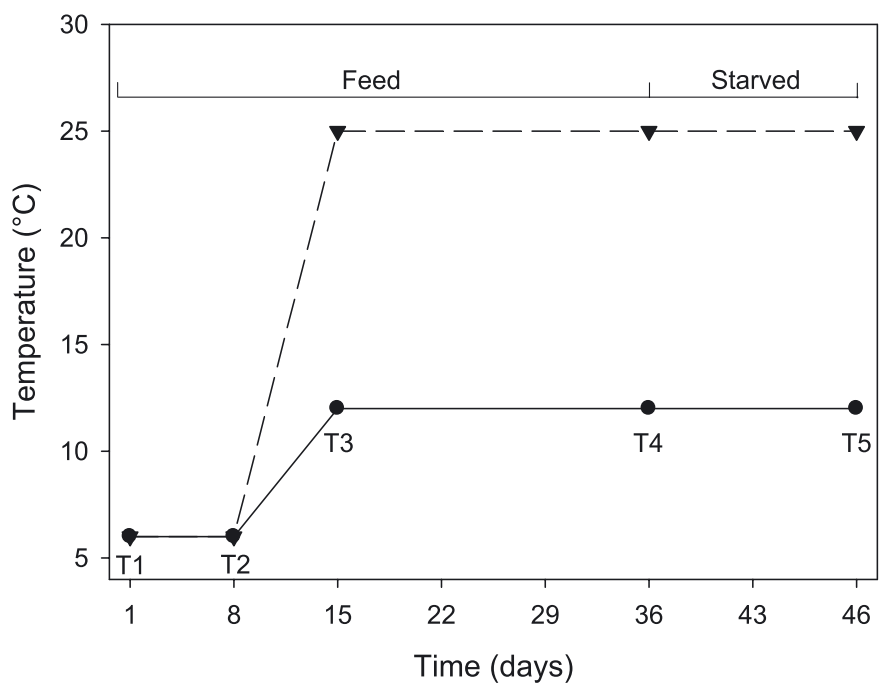

Fig. 2. Experimental protocol of the thermal acclimation experiment. Lipid sampling was done at T1, T2, T3, and T4, and metabolic measurements were made at $\mathrm{T} 4$ and $\mathrm{T} 5$.

filtered $(1 \mu \mathrm{m})$ and UV-treated seawater. At the end of the starvation period (day 46), oxygen uptake measurements were repeated to quantify the specimen's standard metabolism, which is an estimate of maintenance metabolism (Bayne 1973). Following metabolism measurements, tissue dry mass of each specimen was determined after desiccation at $70{ }^{\circ} \mathrm{C}$ for $72 \mathrm{~h}$, and oxygen consumption was standardized using an allometric relationship (Tremblay et al. 1998b).

\subsection{Lethal temperature: $\mathrm{LT}_{50}$ trials}

Aerobic stress was induced at high temperature and low food levels in well-oxygenated water. For this experiment, 100 mussels per stock were divided into two $200 \mathrm{~L}$ tanks (300 mussels per tank) and identified with bee tags (Queen marking kits, The Bee Works, Orillia, Ontario, Canada). Tanks were supplied with flow-through filtered $(1 \mu \mathrm{m})$ seawater at a rate of $2 \mathrm{~L} \mathrm{~min}^{-1}$. Dissolved oxygen was measured (YSI model 58, Yellow Springs, OH, USA) daily and remained above $90 \%$ saturation. The initial experimental water temperature was $3{ }^{\circ} \mathrm{C}$ and was raised between 2 and $4{ }^{\circ} \mathrm{C}$ per day to a maximum of $30{ }^{\circ} \mathrm{C}$ or until a mortality level of $50 \%$ was obtained for each stock ( $\mathrm{LT}_{50}$; Myrand et al. 2002). Survival was determined by pressing the mussel shells together: if the posterior and anterior adductor muscle activated to keep the shells closed, the mussel was considered alive. Each mussel was stimulated (shells pressed together) three times to determine mortality.

\subsection{Reciprocal stocks-sites transplant field experiment}

Twelve condo cages with 32 individual compartments per condo cage (LeBlanc et al. 2005) were filled with a total of 96 mussels (three mussels per compartment). Sixteen mussels 
from each of the six stocks were placed in each condo. Individual mussels were measured (from the umbo to furthest point on the posterior edge) and placed in a fine mesh sock divided into three sections, with one mussel per section. Each sock was placed into a condo unit (compartment) to which it had been randomly assigned. Thus, the set-up consisted of three mussels per compartment, but the placement of each mussel in a sock section kept them separate. Condos were prepared and then placed into one of the three holding tanks until field deployment on 26 October 2004. Two condo cages with a total of 32 specimens per stock were deployed at each of the six study sites; unfortunately, both condo cages were lost at the Shippagan site. The cages were suspended on long lines such that they would not touch bottom. Cages were cleaned in June 2005 and survival was assessed on 6-8 September 2005. Survival was determined by pressing the mussel shells together as already described. In all sites, seawater temperature varied from $-1{ }^{\circ} \mathrm{C}$ to $24-25{ }^{\circ} \mathrm{C}$ over the study period. The profiles were similar and characterized by a decrease in temperature until $-1{ }^{\circ} \mathrm{C}$ in December, an overwintering period until April with stable temperatures of about $-1{ }^{\circ} \mathrm{C}$, and a marked temperature increase until the maximum observed in July-August.

\subsection{Statistical analyses}

Allele frequencies and the observed and expected heterozygosities were obtained using GENETIX 4.05 (Belkhir et al. 1998). The fixation index $F$ is (Weir and Cockerham 1984), a measure of deviation from Hardy-Weinberg equilibrium, was calculated using GENEPOP 4.0 (Rousset 2008). Significant differences between genotypic frequencies were tested using the exact $\mathrm{G}$ test implemented in GENEPOP 4.0. The number of heterozygous loci per mussel (zero to five) was used to characterize individual multi-locus heterozygosities (MLH). Frequency distributions of the number of heterozygous loci between different mussel stocks were compared with a series of one-tailed Wilcoxon tests. A sequential Bonferroni corrections was applied to keep the type I error at the overall level of 0.05 (Rice 1989).

Other statistical tests were performed with SAS 9.2 (SAS Institute Inc., Cary, NC, USA). For each model, residuals were screened for normality using the normal probability plot and then tested using the Shapiro-Wilk's statistic. Homogeneity of variances was graphically assessed using residual plots and further tested using Bartlett's test. When differences were detected, a posteriori comparisons were performed on the LSMEANS and a sequential Bonferroni correction was applied to keep the type I error at the overall level of 0.05 (Rice 1989). Metabolism data were log transformed to normalize data and then compared by a split plot ANCOVA with temperature in the main plot, stock in the subplot, and initial length as the covariate. Lipid concentrations were log transformed and compared by a randomized block ANOVA model with aquarium as the block effect and treatments being combined timetemperature (six levels: day 1 at $6{ }^{\circ} \mathrm{C}$, day 8 at $6{ }^{\circ} \mathrm{C}$, day 15 at $12{ }^{\circ} \mathrm{C}$, day 15 at $25^{\circ} \mathrm{C}$, day 36 at $12^{\circ} \mathrm{C}$, day 36 at $25^{\circ} \mathrm{C}$ ) and stocks (Caraquet, Miramichi, New London, Shippagan, St. Peter Bay and Tracadie) as treatments. Mortality curves in $\mathrm{LT}_{50}$ trials were compared between stocks using a Cox regression model. In the field experiment, growth rates were estimated by subtracting initial length from final length and then compared by a two-way ANOVA model with stocks (6) and sites (5) as factors. Finally, ANOVA was used to determine whether the stocks or sites had a significant effect on the survival rate.

\section{Results}

\subsection{Initial characterization of mussels}

Our analysis of the ITS nuclear marker on the 240 mussels revealed that $M$. trossulus occurred only at Caraquet, where it made up a low percentage of the Mytilus population $(<5 \%)$. The genetic characteristics for all mussel groups are presented in Table 1 . The overall $F$ is values indicate significant deviation from Hardy-Weinberg equilibrium for all stocks, except for mussels from Shippagan and Tracadie. Mussel stocks from Caraquet, Miramichi, St. Peters, and New London showed significant heterozygote deficiencies for 3 to 5 loci, while the stock from Tracadie and Shippagan only had significant deficiencies at one locus (GPI for Shippagan and PGM for Tracadie). Mussel stocks with significant heterozygote deficiencies were also characterized by significantly lower mean multi-locus heterozygosity levels (MLH), ranging from 1.36 to 1.92 compared to 2.37 and 2.48 for Shippagan and Tracadie, respectively. When comparing the six stocks, the only significant differences in genotypic frequencies were detected at the PGM locus $(p=0.019)$. Allele frequencies recorded during this study are similar to those from previous study in Prince Edward Island (LeBlanc et al. 2008).

\subsection{Thermal acclimation experiment}

The main lipid classes detected in seed mussels were triacyclglycerols (TAG), sterols (ST), acetone-mobile polar lipids (AMPL), and phospholipids (PL). Time-temperature and site interacted in their effect on mussel TAG content $\left(F_{25,69}=4.53\right.$, $p<0.001)$. The TAG level in mussel tissues varied significantly during thermal acclimation (from 0.19 to $7.64 \mathrm{mg} \mathrm{g}^{-1}$ wet mass), except for mussels from New London, where no time-temperature effect was observed (Fig. 3). At $12{ }^{\circ} \mathrm{C}$, no TAG accumulation was observed after more than five weeks, while a marked TAG accumulation at day 36 at $25^{\circ}$ was observed in mussels from five locations. Only mussels from New-London did not accumulate TAG at $25^{\circ} \mathrm{C}$. Mussels from Tracadie, Shippagan, and St. Peters Bay showed significantly higher TAG levels at the end of the $25^{\circ} \mathrm{C}$ acclimation period compared to mussels from other locations.

AMPL contain photosynthetic pigments, glycolipids and monoacylglycerol. This lipid class showed no stock effect, but a significant time-temperature effect $\left(F_{25,69}=4.81, p<\right.$ $0.001)$. At the beginning of the thermal acclimation experiment, AMPL represented about $8 \%$ of the total lipids in mussel tissues and increased sharply to $25 \%$ at day 8 and until the end of the experiment, likely reflecting the presence of phytoplankton pigments in mussel digestive tracts. No consistent pattern was observed for ST and PL and variations were relatively low, so these data are not considered further. The mean value for ST 
Table 1. Genetic characteristics of seed mussels collected from different aquaculture sites.

\begin{tabular}{|c|c|c|c|c|c|c|}
\hline & Caraquet & Shippagan & Miramichi & New London & Tracadie & St. Peters \\
\hline \multicolumn{7}{|l|}{ GPI } \\
\hline $\mathrm{N}$ & 40 & 40 & 40 & 40 & 40 & 40 \\
\hline A & 0.123 & 0.143 & 0.151 & 0.148 & 0.127 & 0.137 \\
\hline B & 0.022 & 0.033 & 0.025 & 0.038 & 0.021 & 0.022 \\
\hline $\mathrm{C}$ & 0.180 & 0.164 & 0.154 & 0.144 & 0.134 & 0.133 \\
\hline $\mathrm{D}$ & 0.488 & 0.437 & 0.450 & 0.513 & 0.475 & 0.550 \\
\hline $\mathrm{E}$ & 0.040 & 0.060 & 0.067 & 0.054 & 0.076 & 0.056 \\
\hline $\mathrm{F}$ & 0.147 & 0.163 & 0.153 & 0.103 & 0.157 & 0.102 \\
\hline Ho & 0.375 & 0.225 & 0.400 & 0.325 & 0.550 & 0.550 \\
\hline $\mathrm{He}$ & 0.622 & 0.649 & 0.645 & 0.612 & 0.637 & 0.593 \\
\hline$F$ is & 0.407 & 0.609 & 0.391 & 0.479 & 0.204 & 0.086 \\
\hline \multicolumn{7}{|l|}{ MPI } \\
\hline A & 0.237 & 0.149 & 0.171 & 0.218 & 0.162 & 0.162 \\
\hline $\mathrm{B}$ & 0.763 & 0.851 & 0.803 & 0.782 & 0.838 & 0.838 \\
\hline $\mathrm{C}$ & 0.000 & 0.000 & 0.026 & 0.000 & 0.000 & 0.000 \\
\hline Ho & 0.210 & 0.189 & 0.184 & 0.282 & 0.125 & 0.225 \\
\hline $\mathrm{He}$ & 0.360 & 0.253 & 0.326 & 0.341 & 0.117 & 0.272 \\
\hline$F$ is & 0.429 & 0.265 & 0.445 & 0.185 & -0.054 & 0.186 \\
\hline \multicolumn{7}{|c|}{ ODH } \\
\hline A & 0.037 & 0.025 & 0.050 & 0.075 & 0.037 & 0.025 \\
\hline B & 0.825 & 0.837 & 0.763 & 0.800 & 0.838 & 0.775 \\
\hline $\mathrm{C}$ & 0.138 & 0.138 & 0.187 & 0.125 & 0.125 & 0.200 \\
\hline Ho & 0.150 & 0.325 & 0.125 & 0.350 & 0.125 & 0.150 \\
\hline $\mathrm{He}$ & 0.299 & 0.283 & 0.381 & 0.339 & 0.119 & 0.359 \\
\hline$F$ is & 0.508 & -0.152 & 0.679 & -0.021 & -0.037 & 0.591 \\
\hline \multicolumn{7}{|c|}{ LAP } \\
\hline A & 0.362 & 0.275 & 0.275 & 0.313 & 0.195 & 0.300 \\
\hline B & 0.238 & 0.387 & 0.312 & 0.275 & 0.400 & 0.338 \\
\hline $\mathrm{C}$ & 0.400 & 0.338 & 0.413 & 0.412 & 0.405 & 0.362 \\
\hline Ho & 0.375 & 0.350 & 0.325 & 0.425 & 0.600 & 0.350 \\
\hline $\mathrm{He}$ & 0.652 & 0.665 & 0.657 & 0.657 & 0.601 & 0.665 \\
\hline$F$ is & 0.435 & 0.293 & 0.514 & 0.364 & 0.015 & 0.483 \\
\hline \multicolumn{7}{|c|}{ PGM } \\
\hline A & 0.169 & 0.137 & 0.137 & 0.061 & 0.150 & 0.112 \\
\hline B & 0.536 & 0.600 & 0.613 & 0.572 & 0.525 & 0.625 \\
\hline $\mathrm{C}$ & 0.295 & 0.263 & 0.250 & 0.267 & 0.325 & 0.263 \\
\hline Ho & 0.385 & 0.400 & 0.325 & 0.407 & 0.300 & 0.350 \\
\hline $\mathrm{He}$ & 0.651 & 0.547 & 0.616 & 0.621 & 0.651 & 0.623 \\
\hline$F$ is & 0.419 & 0.262 & 0.482 & 0.368 & 0.548 & 0.448 \\
\hline \multicolumn{7}{|c|}{ All Loci } \\
\hline Но & 0.299 & 0.398 & 0.272 & 0.338 & 0.375 & 0.325 \\
\hline $\mathrm{He}$ & 0.517 & 0.467 & 0.525 & 0.524 & 0.455 & 0.502 \\
\hline$F$ is & 0.432 & 0.185 & 0.492 & 0.295 & -0.054 & 0.364 \\
\hline
\end{tabular}

Allozyme loci analyzed (GPI, MPI, ODH, LAP, PGM). Alleles were named A, B, etc., in order of electrophoretic mobility. Sample size (N), allelic frequencies, the observed proportion of heterozygotes per locus (Ho), Hardy-Weinberg proportions of heterozygotes (He), deviation from Hardy-Weinberg equilibrium ( $F$ is) and multi-locus heterozygosity (MLH). Numbers in bold indicate significant deviation from HardyWeinberg equilibrium. Different letters indicate significant differences of MLH between sites.

was $1.13 \pm 0.05 \mathrm{mg} \mathrm{g}^{-1}$ wet mass and $4.04 \pm 0.16 \mathrm{mg} \mathrm{g}^{-1}$ for PL.

Temperature and stock interacted in their effects on the standard metabolic rate (SMR) of mussels (Fig. 4). At $25^{\circ} \mathrm{C}$, SMR for mussels from Caraquet, Miramichi and New London was $85 \%$ higher than those of mussels from Tracadie, Shippagan and St. Peters Bay. At $12{ }^{\circ} \mathrm{C}$, SMR did not vary among mussels from different sites. Although the ratio of standard to maximum metabolism was not significantly affected by temperature, site, or their interaction, this ratio for mussels from Tracadie and Shippagan was below 0.4 compared to above 0.5 for all other stocks (data not shown). Thus, mussels from Tracadie and Shippagan need about $10 \%$ less energy for their aerobic maintenance requirements. 

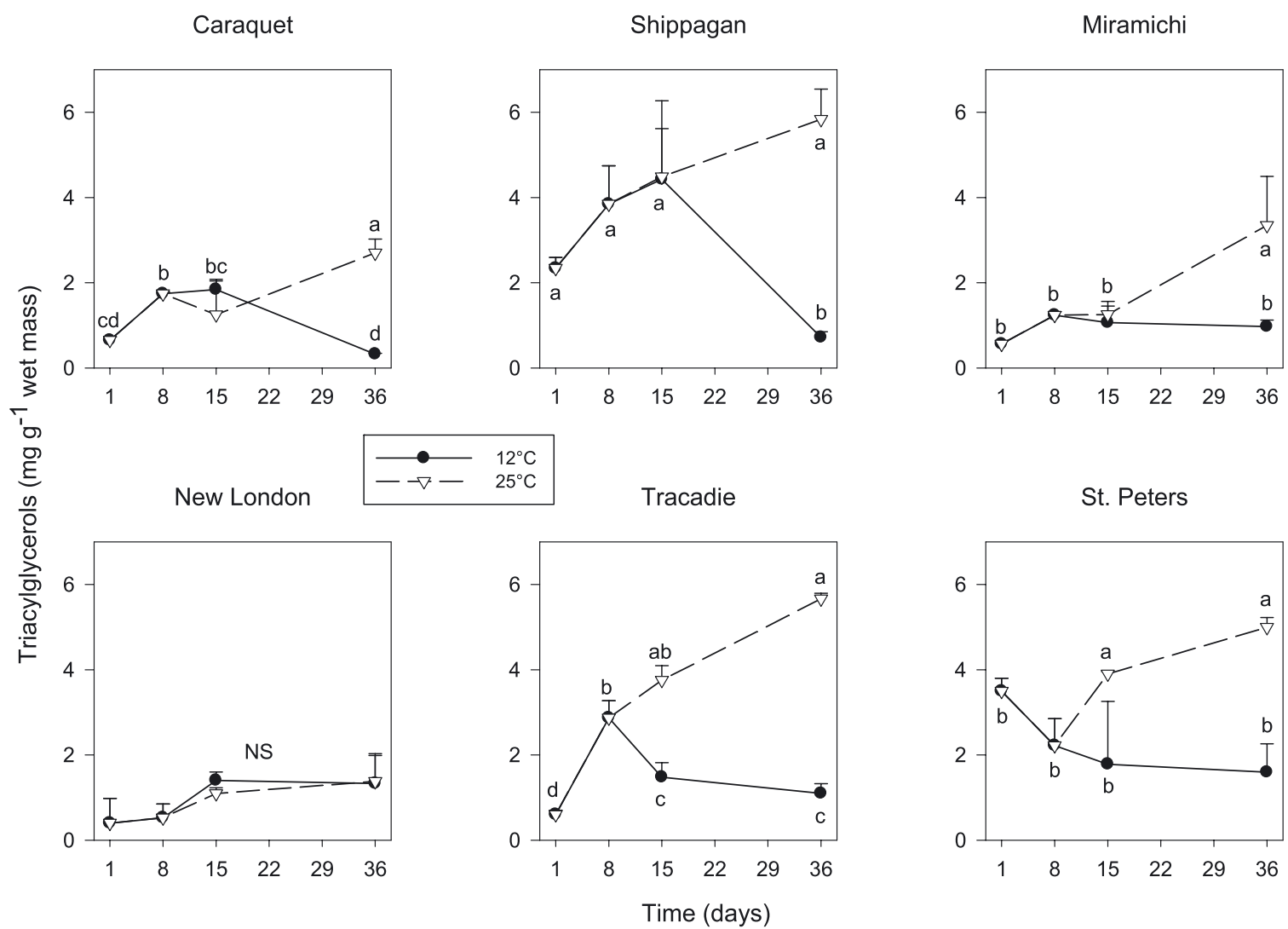

Fig. 3. Triacylglycerol (TAG) content in mussel tissues during acclimation at $12{ }^{\circ} \mathrm{C}$ and $25{ }^{\circ} \mathrm{C}$ in mussels originating from six locations in the southern Gulf of St Lawrence. Different letters indicate significant differences $(p<0.05)$. Data are mean $\pm \mathrm{SE}$.

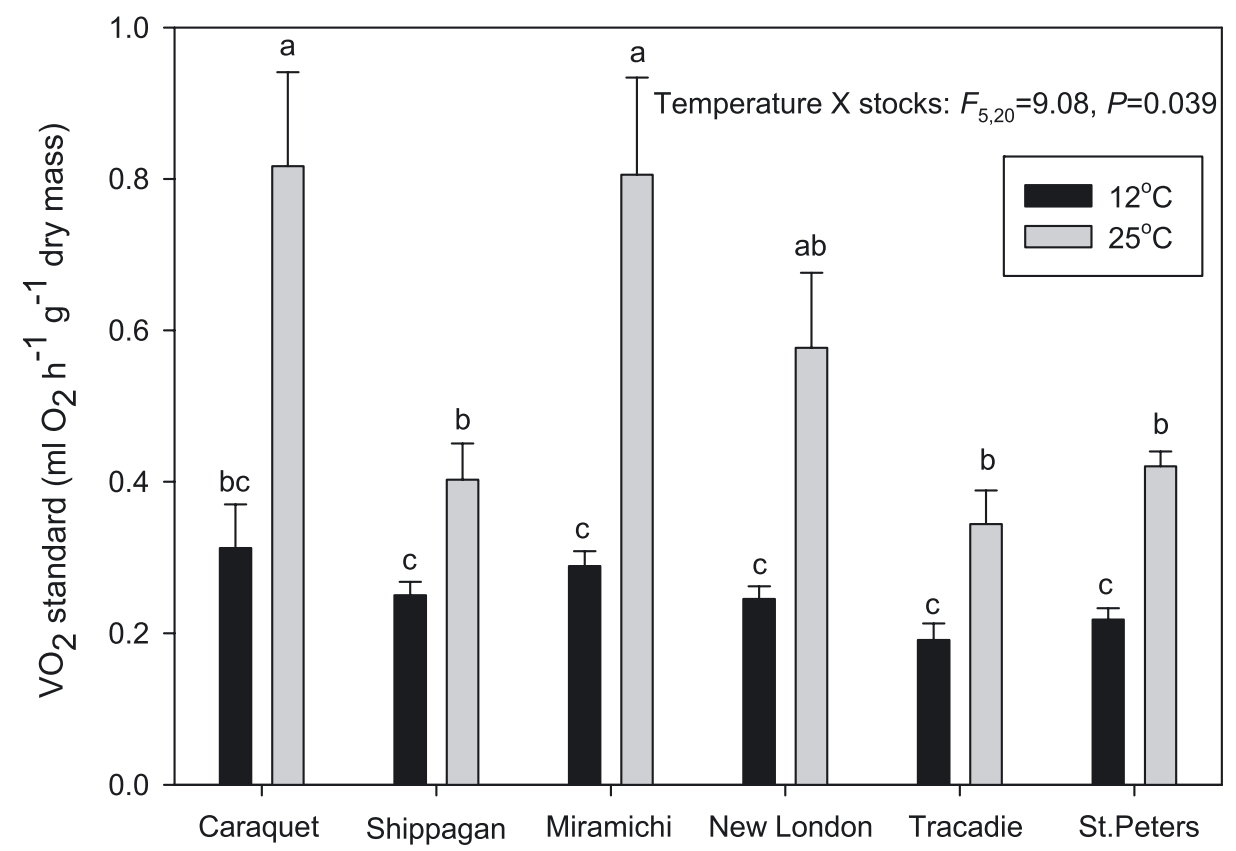

Fig. 4. Standard metabolism ( $\mathrm{V}_{\mathrm{O} 2} \mathrm{~min}$ ) of different mussel stocks after acclimation to $12{ }^{\circ} \mathrm{C}$ and $25^{\circ} \mathrm{C}$. Significant differences are indicated by different letters $(p<0.05)$. Bars show mean \pm SE. 
Table 2. Mean initial length $(\mathrm{mm})$ and growth after 11 months for each stock by site and mean growth by site for each stock (Caraquet, Shippagan, Miramichi, New London, Tracadie, and St. Peters; the experimental apparatus was lost at Shippagan). Mean \pm SE. Different letters indicate significant differences between stocks or between sites.

\begin{tabular}{lccc}
\hline Stocks & $\begin{array}{c}\text { Mean initial } \\
\text { length } \\
(\mathrm{mm})\end{array}$ & $\begin{array}{c}\text { Mean growth } \\
\text { by stock } \\
(\mathrm{mm})\end{array}$ & $\begin{array}{c}\text { Mean growth } \\
\text { by site } \\
(\mathrm{mm})\end{array}$ \\
\hline Caraquet & $16.8 \pm 1.9^{\mathrm{b}}$ & $12.8 \pm 2.5^{\mathrm{a}}$ & $11.7 \pm 2.9^{\mathrm{a}}$ \\
Shippagan & $22.5 \pm 4.2^{\mathrm{a}}$ & $10.7 \pm 2.4^{\mathrm{b}}$ & \\
Miramichi & $18.1 \pm 1.9^{\mathrm{b}}$ & $12.1 \pm 3.7^{\mathrm{ab}}$ & $10.5 \pm 2.6^{\mathrm{b}}$ \\
New London & $22.9 \pm 3.3^{\mathrm{a}}$ & $9.6 \pm 2.7^{\mathrm{c}}$ & $11.3 \pm 2.3^{\mathrm{ab}}$ \\
Tracadie & $24.9 \pm 2.6^{\mathrm{a}}$ & $11.4 \pm 2.4^{\mathrm{ab}}$ & $10.2 \pm 2.3^{\mathrm{b}}$ \\
St. Peters & $24.1 \pm 3.3^{\mathrm{a}}$ & $9.8 \pm 2.1^{\mathrm{c}}$ & $10.6 \pm 2.4^{\mathrm{b}}$ \\
\hline
\end{tabular}

Initial length: $F_{5,541}=17.74, p<0.001$. Growth, Stock: $F_{5,541}=$ 5.74, $p<0.001$; Site: $F_{4,541}=4.58, p=0.001$.

\section{$3.3 \mathrm{LT}_{50}$ trials}

A comparison of the mortality pattern showed that mussels from Tracadie and Shippagan had a significantly lower mortality levels after exposure to an acute temperature increase (from 3 to $30^{\circ} \mathrm{C}$ ), after 8 days, compared to mussels from Miramichi, Caraquet and New London. Mussels from St. Peters Bay showed intermediate values (Fig. 5). No significant mortalities were obtained until day 6 , and by day 7 differential mortalities between stocks were already observed. Initial shell length had no impact on survival during this stress experiment.

\subsection{Reciprocal stocks-sites transplant field experiment}

The initial mussel length was significantly lower for mussels from Caraquet and Miramichi compared to all other stocks (Table 2). Growth rates for each stock at each site were estimated by subtracting initial length from final length after 11 months of growth. The condo cages from the Shippagan site were lost, so analyses are limited to the five remaining sites. The average growth of mussels between October 2004 and September 2005 was $10.8 \pm 2.6 \mathrm{~mm}$ with significant differences between sites and stocks, but there was no significant interaction between site and stock (Table 2). Mussels from Caraquet, Miramichi, and Tracadie showed the highest growth rates followed by mussels from Shippagan. Mussels from St. Peters Bay and New London had the lowest growth rates at all sites, with a difference of $30 \%$. For all mussel stocks, the growth rate at Caraquet was $15 \%$ higher compared to mussels kept in Miramichi, Tracadie, and St. Peters Bay. New London showed intermediate values.

We observed an interaction in the effects of stocks and sites on mussel survival (Table 3). Mussels from Shippagan, Tracadie, and St. Peters Bay clearly showed higher survival, with mean values of $61 \pm 4 \%$ (mean for all sites). Mussels from Caraquet, Miramichi, and New London showed a mean survival of only $28 \pm 5 \%$. Higher survival of mussels from Shippagan, Tracadie and St. Peters was observed in all sites.
Differences in survival among sites varied only slightly between $42 \pm 14 \%$ at Tracadie to $49 \pm 11 \%$ at Miramichi.

\section{Discussion}

This study, conducted in both controlled and natural environments, clearly shows the potential for discriminating the quality of mussel seed stock sampled on artificial collectors from different locations within a single bio-geographical area, i.e., the Gulf of St Lawrence. We showed that seed depending of the origin, can significantly affect the potential for mussels to survive and grow in natural conditions. Indeed, mussels from Tracadie and Shippagan had the highest quality based on two factors, a lower $F$ is and higher MLH. The factor MLH represents higher level of heterozygosity, lower basal metabolism, higher accumulation of lipid reserve under high water temperature conditions, and higher survival in a controlled stress event (i.e. $\mathrm{LT}_{50}$ ) as well as under natural conditions (in the field). Thus, mussels from Tracadie and Shippagan seem to have the best capacity to survive in high water temperatures, which frequently occur in bays of these areas during summer period. Mussel seed from St. Peters Bay had the next highest score.

A previous study on Mytilus edulis indicated that individuals with high levels of multi-locus heterozygosity (MLH) measured on allozymes involved in metabolism show lower basal metabolic rates and higher resistance to summer mortality compared to those with low MLH (Tremblay et al. 1998b). Our study agrees with previous studies that showed positive correlations between MLH and traits relate to fitness (Koehn and Gaffney 1984; Gentili and Beaumont 1988; Brokordt et al. 2009). Although the relationship between MLH and fitness is somewhat controversial (Britten 1996), several studies showed that positive correlations are attributable to a more efficient use of energy in heterozygous individuals. The effect of MLH on fitness is particularly visible in animals exposed to stressful conditions (Gentili and Beaumont 1988; Beaumont and Toro 1996; Myrand et al. 2002; Lesbarreres et al. 2005). Our study confirms that MLH of allozymes involved in metabolic activity is a good indicator of survival in mussels, as already proposed in previous studies (Myrand et al. 2002; LeBlanc et al. 2005). In addition to these previous works, we show here for the first time that differences in MLH and standard metabolic rates among mussel seeds of different origins were consistent with differences in TAG levels at high temperature. This finding agrees well with the fact that TAG is a proxy of energy reserves in bivalves including mussels (Gallager et al. 1986; Freites et al. 2002; Pernet et al. 2007; Prato et al. 2010).

Our results showed marked TAG accumulation during acclimation at $25{ }^{\circ} \mathrm{C}$ from all stocks except those from New London. There was no similar accumulation in TAG after five weeks of acclimation at $12{ }^{\circ} \mathrm{C}$, likely reflecting the fact that filtration rate and food acquisition in mussels increases at high temperatures (Pernet et al. 2007). However, these authors showed that TAG in mussel digestive gland decreases when temperature was gradually increased from $0{ }^{\circ} \mathrm{C}$ to $20^{\circ} \mathrm{C}$. This apparently paradoxical result may reflect the reallocation of TAG reserves from the digestive gland to the mantle for sustaining gamete production, which normally occurs when 


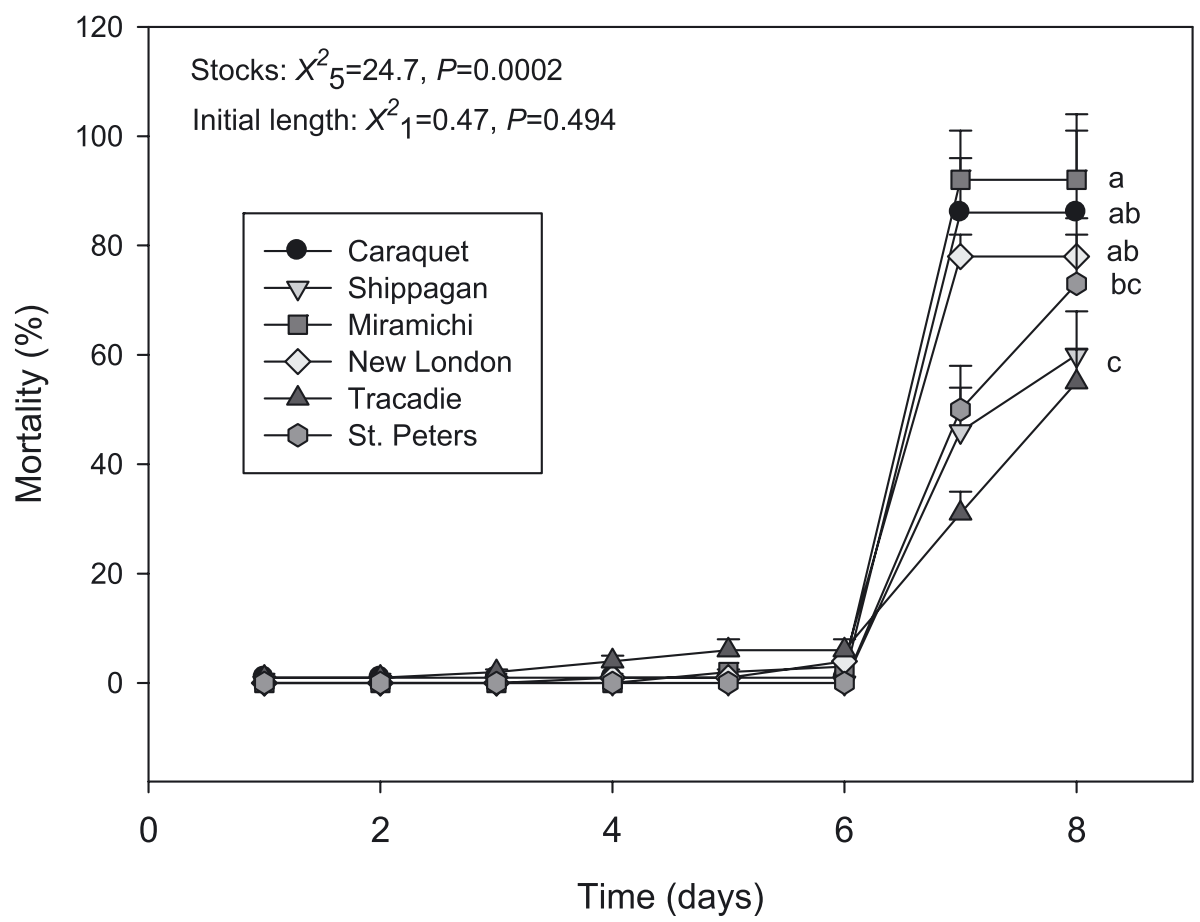

Fig. 5. Survival of mussels from different stocks facing aerobic stress conditions (well aerated, no food, temperature of $30{ }^{\circ} \mathrm{C}$ ). The initial number of mussels per stock was 100 .

Table 3. Results from the reciprocal stocks-sites transplant experiment: mean survival (\% $\pm \mathrm{SE}$ ) of mussels from six different stocks (Caraquet, Shippagan, Miramichi, New London, Tracadie, St. Peters Bay) after 11 month in five different sites (the experimental apparatus was lost at the Shippagan site). Different letters indicate significant differences between stocks at each site.

\begin{tabular}{|c|c|c|c|c|c|c|}
\hline \multirow[b]{2}{*}{ Sites } & \multicolumn{6}{|c|}{ Stocks } \\
\hline & Caraquet & Shippagan & Miramichi & New London & Tracadie & St. Peters \\
\hline Caraquet & $22.3 \pm 9.5^{\mathrm{c}}$ & $68.9 \pm 7.4^{\mathrm{a}}$ & $27.5 \pm 14.1^{\mathrm{bc}}$ & $34.2 \pm 5.3^{b}$ & $61.1 \pm 3.9^{\mathrm{a}}$ & $60.5 \pm 3.3^{\mathrm{a}}$ \\
\hline Miramichi & $31.6 \pm 4.2^{\mathrm{b}}$ & $62.3 \pm 6.2^{\mathrm{a}}$ & $38.9 \pm 6.8^{b}$ & $35.4 \pm 6.6^{\mathrm{b}}$ & $64.5 \pm 2.4^{\mathrm{a}}$ & $69.4 \pm 2.1^{\mathrm{a}}$ \\
\hline New London & $25.3 \pm 2.7^{\mathrm{a}}$ & $62.1 \pm 2.5^{\mathrm{a}}$ & $26.8 \pm 5.8^{\mathrm{a}}$ & $39.6 \pm 6.6^{\mathrm{b}}$ & $49.7 \pm 9.7^{\mathrm{a}}$ & $58.8 \pm 2.6^{\mathrm{a}}$ \\
\hline Tracadie & $18.7 \pm 5.5^{\mathrm{c}}$ & $69.9 \pm 4.8^{\mathrm{a}}$ & $19.2 \pm 5.8^{c}$ & $26.4 \pm 9.2^{c}$ & $54.8 \pm 3.1^{\mathrm{b}}$ & $54.3 \pm 2.2^{b}$ \\
\hline St. Peters & $30.3 \pm 7.4^{\mathrm{c}}$ & $66.8 \pm 5.4^{\mathrm{a}}$ & $18.7 \pm 6.6^{\mathrm{d}}$ & $40.1 \pm 5.8^{c}$ & $65.5 \pm 5.9^{\mathrm{a}}$ & $53.4 \pm 2.4^{\mathrm{b}}$ \\
\hline
\end{tabular}

Survival, Stocks X Sites: $F_{20}=32.63, p=0.037$.

temperature increases. In our study, the short period of acclimation (five weeks) was probably not sufficient for such reallocation to take place. We also observed that mussels from Tracadie, Shippagan and St. Peters Bay accumulated higher level of TAG at the end of acclimation period at $25^{\circ} \mathrm{C}$. Differences between stocks seem to be related to a lower standard (maintenance) metabolism in mussels from Tracadie, Shippagan and St. Peters Bay at $25^{\circ} \mathrm{C}$. Because standard metabolism represents energy required for vital function (Bayne 1973), mussels from these stocks have more energy to allocate to other functions and can thus accumulate more energy reserves, like TAG.

Our results showed that the use of stressful conditions, like high temperature, seems to be a good way to assess the potential for seed survival in different aquaculture sites, as was previously suggested by Leblanc et al. (2005). During the aerobic stress experiment, we observed that mussels from Tracadie and Shippagan had significantly lower mortality levels, as was the case for the stocks-sites experiments. However, our results on mussels do not seem applicable for all bivalves. A recent study on the Pacific oyster, Crassostrea gigas, reported that an immersion-based heat shock stress did not affect growth and survival of adult oyster families in the North Pacific region of the US (Lang et al. 2010).

Mussels from Tracadie and Shippagan showed the highest survival at all sites; mussels from St. Peters Bay were intermediate, whereas those from Caraquet, Miramichi, and New London showed the lowest survival. Interestingly, a previous study showed that mussel seed from Tracadie had a high survival potential compared to those from the Boughton and Murray rivers in Prince Edward Island (Mallet et al. 1990). The results from our stocks-sites transfer study seem to follow the general trend, where stock origin explains most of the variance in mortality while environmental conditions from the host site and the initial shell length are more important in explaining the variance in growth (Mallet et al. 1990; Fuentes et al. 1992; Myrand and Gaudreault 1995).

In this study, we observe minimal PL and sterols fluctuations and no consistent pattern. PL are involved in various 
structural functions of cells (Freites et al. 2002; Prato et al. 2010), and sterols, particularly cholesterol, form part of the cell membranes and can affect the physical properties of membranes, such as their permeability (Crockett 1998). A widely accepted notion is that cholesterol stabilizes membranes, i.e. it increases the order of the surrounding acyl chains in membranes in the fluid phase at high temperatures, as observed in ectothermic animals (Crockett 1998; Zehmer and Hazel 2003). However, as there were no significant increases in sterol content in our study, mussels did not seem to use cholesterol in their membranes to decrease fluidity at the higher temperature $\left(25^{\circ} \mathrm{C}\right.$ vs. $\left.12^{\circ} \mathrm{C}\right)$. A lack of increased sterol content in mussels at temperatures over $20^{\circ} \mathrm{C}$ was previously reported, suggesting that these animals may have other mechanisms for maintaining membrane fluidity at high temperatures (Pernet et al. 2007). However, these results could also be explained by the microalgae used to feed mussels during our acclimation experiment. Microalgae contain a complex mixture of phytosterols, that generally include only low levels of cholesterol (Tremblay et al. 2007). These phytosterols have less ordering effect on membrane fluidity than cholesterol (Suckling et al. 1979).

The presence of two blue mussel species, Mytilus edulis and Mytilus trossulus, was detected in this bio-geographical area, although $M$. trossulus was observed at the very low level (5\%) and only at one site, Caraquet Bay. This result may provide some indications that the high experimental water temperature of $25^{\circ} \mathrm{C}$ can occur on a regular basis in most bays in the southern Gulf of St-Lawrence, and particularly in the studied sites. The thermal tolerance of mussel larvae is species-specific with $M$. trossulus larvae having a lower survival success at $24{ }^{\circ} \mathrm{C}$ (Rayssac et al. 2010). Low survival of M. trossulus larvae at high temperatures is reflected by the distribution of these two species, with $M$. trossulus having a more northerly distribution compared to the more temperate distribution of M. edulis (Gosling 1992). In contrast, the survival of juveniles at high temperatures is similar between the two species (Rayssac et al. 2010). Therefore, the absence of M. trossulus on artificial collectors at all sampling sites, except Caraquet likely reflects the effect of elevated summer seawater temperature that are not tolerated by $M$. trossulus larvae.

\section{Conclusion}

Our results showed that more heterozygote mussels, with their lower standard metabolism, rely less on their energy reserves to maintain vital functions; energy is thus available to support physiological responses to stress at high temperature. Thus, mussels from Tracadie and Shippagan had more energy to resist stressful events and showed lower mortality. We suggest that MLH at loci coding for metabolic enzymes, and $\mathrm{LT}_{50}$, at high temperatures could be good indicators to assess the potential survival of mussels stocks in warm shallow bays of the Gulf of St Lawrence. The survival of mussels submitted to a high temperature stress event $\left(\mathrm{LT}_{50}\right)$ could be an easy and practical tool for assessing mussel's seed stocks resistance. The determination of MLH could be used to identify mussel stocks most appropriated for aquaculture, particularly for the identification of mussel stocks with a minimum of deviation from Hardy-Weinberg equilibrium.
Given that mussel aquaculture occurs in small, highly protected area in the southern Gulf of St Lawrence (Comeau et al. 2008), where seawater temperatures can reaches $25^{\circ} \mathrm{C}$ during the summer (Waite et al. 2005; Pernet et al. 2006; Smith 2009). The productivity of the mussel industry may benefit from the use of stocks best able to support high temperatures, particularly in periods of increasing water temperatures.

Acknowledgements. Thanks are extended to Gaétan Daigle, Département de mathématique et statistique, Université Laval, Québec, for validating the statistical analyses and to Laure Devine for English revision. This project was supported by the the Aquaculture Collaborative Research and Development Program (ACRDP) of Fisheries and Oceans, Canada, to TL and the Canada Research Chair program to RT.

\section{References}

Bayne B.L., 1973, Aspects of the metabolism of Mytilus edulis during starvation. Neth. J. Sea Res. 37, 399-410.

Beaumont A.R., Hawkins M.P., Doig F.L., Davies I.M., Snow M., 2008, Three species of Mytilus and their hybrids identified in a Scottish Loch: natives, relicts and invaders? J. Exp. Mar. Biol. Ecol. 367, 100-110.

Beaumont A.R., Toro J., 1996, Allozyme genetics of Mytilus edulis subjected to copper and nutritive stress. J. Mar. Biol. Assoc. UK 76, 1061-1071.

Belkhir K., Borsa P., Goudet J., Chikhi L., Bonhomme F., 1998, Genetix, logiciel sous WindowsMT pour la génétique des populations. Laboratoire génome et populations, CNRS UPR 9060, Université de Montpellier II.

Britten H.B., 1996, Meta-analyses of the association between multilocus heterozygosity and fitness. Evolution 50, 2158-2164.

Brokordt K., Leiva N., Jeno K., Martínez G., Winkler F., 2009, Effect of allozyme heterozygosity on basal and induced levels of heat shock protein (Hsp70), in juvenile Concholepas concholepas (Mollusca). J. Exp. Mar. Biol. Ecol. 370, 18-26.

Comeau L.A., Drapeau A., Landry T., Davidson J., 2008, Development of longline mussel farming and the influence of sleeve spacing in Prince Edward Island, Canada. Aquaculture 281, 56-62.

Crockett E.L., 1998, Cholesterol function in plasma membranes from ectotherms: membrane-specific roles in adaptation to temperature. Am. Zool. 38, 291-304.

Folch J., Lees M., Sloane-Stanlez G.H., 1957, A simple method for the isolation and purification of total lipids from animal tissues. J. Biol. Chem. 226, 497-509.

Freites L., Fernandez-Reiriz M.J., Labarta U., 2002, Lipid classes of mussel seeds Mytilus galloprovincialis of subtidal and rocky shore origin. Aquaculture 207, 97-111.

Fuentes J., Reyero I., Zapata C., Alvarez G., 1992, Influence of stock and culture site on growth rate and mortality of mussels (Mytilus galloprovincialis Lmk.) in Galicia, Spain. Aquaculture 105, 131142.

Gallager S.M., Mann R., Sasaki G.C., 1986, Lipid as an index of growth and viability in three species of bivalve larvae. Aquaculture 56, 81-103.

Gentili M.R., Beaumont A.R., 1988, Environmental stress, heterozygosity, and growth rate in Mytilus edulis L. J. Exp. Mar. Biol. Ecol. 120, 145-153. 
Gosling E., 1992, Systematics and geographic distribution of Mytilus. In: Gosling E. (Ed.), The mussel Mytilus: ecology, physiology, genetics and culture, Amsterdam, Elsevier, pp. 1-20.

Hawkins A.J.S., J. Widdows A.R., Bayne B.L., 1989, The relevance of whole-body protein metabolism to measured costs of maintenance and growth in Mytilus edulis. Physiol. Zool. 62, 745-763.

Heath D.D., Rawson P.D., Hilbish T.J., 1995, PCR-based nuclear markers identify alien blue mussel (Mytilus spp.) genotypes on the west coast of Canada. Can. J. Fish. Aquat. Sci. 52, 26212627.

Johnson S.B., Geller J.B., 2006, Larval settlement can explain the adult distribution of Mytilus californianus Conrad but not of M. galloprovincialis Lamarck or M. trossulus Gould in Moss Landing, central California: evidence from genetic identification of spat. J. Exp. Mar. Biol. Ecol. 328, 136-145.

Koehn R.K., Gaffney P.M., 1984, Genetic heterozygosity and growth rate in Mytilus edulis. Mar. Biol. 82, 1-7.

Lane D.J.W., Beaumont A.R., Hunter J.R., 1985, Byssus drifting and the drifting threads of the young post-larval mussel Mytilus edulis. Mar. Biol. 84, 301-308.

Lang R.P., Langdon C.J., Taris N.G., Camara M.D., 2010, Use of laboratory assays to predict subsequent growth and survival of Pacific oyster (Crassostrea gigas) families planted in coastal waters. Aquaculture 306, 68-79.

LeBlanc N., Landry T., Stryhn H., Tremblay R., McNiven M., Davidson J., 2005, The effect of high air and water temperature on juvenile Mytilus edulis in Prince Edward Island, Canada. Aquaculture 243, 185-194.

LeBlanc N., Tremblay R., Davidson J., Landry T., McNiven M., 2008, The effect of selection treatments on Mytilus edulis, modifications of genetic and physiological characteristics. Mar. Biol. 153, $1142-1152$.

Lesbarreres D., Primmer C., Laurila A., Juha M., 2005, Environmental and population dependency of genetic variabilityfitness correlations in Rana temporaria. Mol. Ecol. 14, 311-323.

Mallet A., Myrand B., 1995, The culture of the blue mussel in Atlantic Canada. In: Boghen A.D. (Ed.), Cold-Water Aquaculture in Atlantic Canada, 2nd edn., Moncton, Canada, Canadian Institute for Research on Regional Development, pp. 255-296.

Mallet A.L., Carver C.E.A., Freeman K.R., 1990, Summer mortality of the blue mussel in eastern Canada: spatial, temporal, stock and age variation. Mar. Ecol. Prog. Ser. 67, 35-41.

Moreau V., Tremblay R., Bourget E., 2005, Distribution of Mytilus edulis and M. trossulus on the Gaspe coast in relation to spatial scale. J. Shellfish Res. 24, 545-551.

Myrand B., Gaudreault J., 1995, Summer mortality of blue mussels (Mytilus edulis Linneaus, 1758) in the Magdalen Islands (southern Gulf of St Lawrence, Canada). J. Shellfish Res. 14, 395-404.

Myrand B., Tremblay R., Sévigny J.-M., 2002, Selection against blue mussels (Mytilus edulis L.) homozygotes under various stressful conditions. J. Hered. 93, 238-248.

Nicastro K.R., Zardi G.I., McQuaid C.D., Teske P.R., Barker N.P., 2008, Coastal topography drives genetic structure in marine mussels. Mar. Ecol. Prog. Ser. 368, 189-195.

Palumbi S.R., 1992, Marine speciation on a small planet. Trends Ecol. Evol. 7, 114-118.

Parrish C.C., 1999, Determination of total lipid, lipid classes, and fatty acids in aquatic samples. In: Arts M.T., Wainman B.C. (Eds.), Lipids in freshwater ecosystems, New York, SpringerVerlag, pp. 4-20.

Pernet F., Tremblay R., Comeau L., Guderley H., 2007, Temperature adaptation in two bivalve species from different thermal habitat: energetics and remodeling of membrane lipids. J. Exp. Biol. 210, 2999-3014.
Pernet F., Tremblay R., Gionet C., Landry T., 2006, Lipid remodeling in wild and selectively bred hard clams at low temperatures in relation to genetic and physiological parameters. J. Exp. Biol. 209, 4663-4675.

Prato E., Danieli A., Maffia M., Biandolino F., 2010, Lipid and fatty acid compositions of Mytilus galloprovincialis cultured in the Mar Grande of Taranto (Southern Italy): feeding strategies and trophic relationships. Zool. Stud. 49, 211-219.

Rayssac N., Pernet F., Lacasse O., Tremblay R., 2010, Temperature effect on survival, growth, and triacylglycerol content during the early ontogeny of Mytilus edulis and M. trossulus. Mar. Ecol. Prog. Ser. 417, 183-191.

Rice W.R., 1989, Analyzing tables of statistical tests. Evolution 43, 223-225.

Ridgway G., 2001, Interpopulation variation in blue mussels, Mytilus edulis L., over short distances. Sarsia 86, 157-161.

Rousset F., 2008, GENEPOP'007: a complete re-implementation of the GENEPOP software for Windows and Linux. Mol. Ecol. Notes 8, 103-106.

Siegel D.A., Kinlan B.P., Gaylord B., Gaines S.D., 2003, Lagrangian descriptions of marine larval dispersion. Mar. Ecol. Prog. Ser. 260, 83-96.

Siegel D.A., Mitarai S., Costello C.J., Gaines S.D., Kendall B.E., Warner R.R., Winters K.B., 2008, The stochastic nature of larval connectivity among nearshore marine populations. Proc. Nat. Acad. Sci. USA 105, 8974-8979.

Smith G., 2009, P E I Mussel Monitoring Program. Technical Report No. 243.

Star B., Apte S., Gardner J.P.A., 2003, Genetic structuring among populations of the greenshell mussel Perna canaliculus revealed by analysis of randomly amplified polymorphic DNA. Mar. Ecol. Prog. Ser. 249, 171-182.

Suckling K.E., Blair H.A.F., Boyd G.S., Craig I.F., Malcolm B.R., 1979, The importance of the phospholipid bilayer and the length of the cholesterol molecule in membrane structure. Biochim. Biophys. Acta 551, 10-21.

Thompson R.J., Bayne B.L., 1972, Active metabolism associated with feeding in the mussel Mytilus edulis L. J. Exp. Mar. Biol. Ecol. 9, 111-124.

Toro J.E., Ojeda J.A., Vergara A.M., 2004, The genetic structure of Mytilus chilensis (Hupe, 1854) populations along the Chilean coast based on RAPDs analysis. Aquac. Res. 35, 1466-1471.

Tremblay R., Cartier S., Miner P., Pernet F., Quéré C., Moal J., Muzellec, Mazuret M., Samain J.-F., 2007, Effect of Rhodomonas salina addition to a standard hatchery diet during the early ontogeny of the scallop Pecten maximus. Aquaculture 262, 410 418.

Tremblay R., Myrand B., Sevigny J.-M., 1998a, Genetic characterization of wild and suspension-cultured blue mussels (Mytilus edulis Linnaeus, 1758) in the Magdalen Islands (southern Gulf of St. Lawrence, Canada). J. Shellfish Res. 17, 1191-1202.

Tremblay R., Myrand B., Sévigny J.-M., Blier P., Guderley H., 1998b, Bioenergetic and genetic parameters in relation to susceptibility of blue mussels, Mytilus edulis (L.) to summer mortality. J. Exp. Mar. Biol. Ecol. 221, 27-58.

Waite L., Grant J., Davidson J., 2005, Bay-scale spatial growth variation of mussels Mytilus edulis in suspended culture, Prince Edward Island, Canada. Mar. Ecol. Prog. Ser. 297, 157-167.

Weir B.S., Cockerham C.C., 1984, Estimating F-statistics for the analysis of population structure. Evolution 38, 1358-1370.

Zehmer J.K., Hazel J.R., 2003, Plasma membrane rafts of rainbow trout are subject to thermal acclimation. J. Exp. Biol. 206, 16571667. 